\title{
Hanuš Věnceslav Tůma ve sporu s pražskou kritikou
}

Martin Hrdina

\begin{abstract}
Disputes of Hanuš Věnceslav Tůma with Prague reviewers

The analysis of selected literary reviews deals with Hanuš Věnceslav Tůma, a forgotten poet whose debuts faced sharp criticism in the first months of 1872. Several important representatives of Czech literary milieu opposed Tůma, pointing out the low aesthetic value of his works. The study focuses on circumstances of the time, uncovering the significant distaste of cultural center representatives for manifestation of emancipation in region-based literary periphery. This dichotomy exhibits one of the structural features of the contemporary literary field and a significant factor influencing the critical reception of this field's production.
\end{abstract}

\section{KEYWORDS}

Literary criticism; center vs. periphery; Hanuš Věnceslav Tůma; Vítězslav Hálek; Umělecká beseda.

\section{KLÍčOVÁ SLOVA}

Literární kritika; centrum vs. periferie; Hanuš Věnceslav Tůma; Vítězslav Hálek; Umělecká beseda.

Závěr šedesátých let 19. století byl jednou z nejvzrušenějších dob v moderních českých dějinách. Zavedení dualismu, jež následovalo po krátké prusko-rakouské válce, vyvolalo v české části Rakouského císařství vlnu veřejných protestů. Pořádaly se masové demonstrace, $\mathrm{z}$ nichž nejvýznamnější bylo položení základního kamene k budově Národního divadla 16. května 1868. Na aktivizované české kulturní scéně se v té době objevila řada nových jmen. Zvlášt vydatně se rozhojnil počet mladých básníků - ti vstupovali do veřejného dění přes stránky přiležitostných almanachů a kulturně zaměřených časopisů, někteří dospěli 
v následujících letech i ke knižnímu vydání svých veršů. Zájem dorůstající generace o básnické tvoření byl přitom logický. Jak konstatoval Jan Mukařovský, právě v šedesátých letech 19 . století u nás bylo „uzákoněno privilegované postavení básnictví v národní kultuře a tím i básníka v sociálním kontextu" (MUKAŘOVSKÝ 1948: 180).

Př́liv nových jmen byl ze strany umělců etablovaných již na poli české literatury nepochybně vítaný, na druhou stranu však signalizoval potenciální změny v poměru sil a mohl vzbuzovat ostražitost. Pierre Bourdieu uvažoval o takových situacích, nastalých $\mathrm{v}$ ohraničených polích produkce určitého typu, následovně: „Velké zvraty se rodí z vpádů nových členů, kteří jen na základě svého počtu a společenské jakosti zavádějí inovace $\mathrm{v}$ oblasti produktů i výrobních technik a mají sklon nebo snahu prosadit ve výrobním poli, které je samo sobě vlastním trhem, nový způsob oceňování výrobkü“ (BOURDIEU 2010: 296). V dobách, kdy se určité pole rozšiřuje o nově příchozí producenty, podle Bourdieua držitelé existujících pozic hájí zavedený řád tím, že se snaží „vymezit hranice, bránit je, hlídat vstupy“ (IBID.: 296). Jednomu konkrétnímu případu, kdy se tyto praktiky projevily v uvedeném historickém kontextu, je věnována následující studie.

V prvních měsících roku 1872 se odehrála polemika mezi Hanušem Věnceslavem Tůmou, jenž byl jedním z básníků vstupujících na sklonku šedesátých let do české literatury, a několika významnými reprezentanty této sféry. Předmětem polemiky bylo kritické přijetí Tůmových básnických prvotin. Tůmova poezie byla zjevně kvalitativně podprůměrná, nejednalo se tedy primárně o to, zda její autor vnáší do pole výrazné inovace, jak měl na mysli Bourdieu v citované úvaze. Tím překvapivější je však razance, s níž představitelé české literatury postupovali při vytěsnění Tůmy z prestižního pole básnické produkce. Kritické negociace o estetické hodnotě textů dávno zapomenutého básníka se tak jeví jako vhodné východisko $\mathrm{k}$ popisu hlubších strukturních rysů soudobého českého literárního pole, sil působících v něm a vztahů mezi nimi, jak se manifestovaly v rozmanitých podobách literární kritiky.

V úvodu studie budou připomenuta základní biografická data o prakticky neznámém autorovi, dále je zevrubně popsáno kritické přijetí jeho díla a reakce autora na ně. Analýza směřuje k odkrytí tenzí existujících v soudobém literárním poli a v závěru se zaměřuje na pozici jednoho z účastníků Tůmovy aféry, Vítězslava Hálka, a jeho reakci na proběhlý spor. 


\section{Adept básnického umění}

Hanuš Věnceslav Tůma (vlastním jménem Jan Václav Tůma, 1846-1910) byl vrstevníkem známých literátů Svatopluka Čecha a Serváce Hellera, s nimiž se také setkal na studiích $\mathrm{v}$ pražském arcibiskupském semináři. Po maturitě roku 1865 studoval klasickou filologii na pražské filozofické fakultě. ${ }^{1}$ Jeho literární tvorbu z té doby dokumentuje sešit, do něhož si v letech 1866-1867 zapisoval básně, arabesky a črty ze studentského života, z nichž se uveřejnění dočkala jen nepatrná část. ${ }^{2} \mathrm{O}$ úctě, jakou Tůma $\mathrm{v}$ této době choval $\mathrm{k}$ čelnému představiteli českého básnictví Vítězslavu Hálkovi, svědčí, že jako moto do sešitu svých prvotin vepsal jednu z jeho písní (TU゚MA 1866-1867). ${ }^{3}$

V letech 1868-1870 Tůma v Praze pracoval jako učitel a začal též docházet na schůze Literárního odboru Umělecké besedy. ${ }^{4}$ Měl tak př́ležitost sledovat dění v klíčové kulturní instituci, sídlící v centru českého veřejného života, a poznat některé známé osobnosti, které do něho zasahovaly. Například na schůzi 12. března 1870, jíž byl Tůma podle dochované prezenční listiny přítomen, ${ }^{5}$ přednášel v literárním odboru Otakar Hostinský o Richardu Wagnerovi a v následující živé debatě vystoupili Jaroslav Goll, Vítězslav Hálek a Josef Durdík (UMĚLECKÁ BESEDA 1867-1873). V této společnosti se však Tůma zdržel jen několik týdnů - život jej zavál do Klatov, kde získal místo suplenta na gymnáziu. ${ }^{6}$ Tůma si nad svým osudem pozasteskl, když v den sv. Kateřiny roku 1871 psal předmluvu ke knize svých Básní: „Mnohé a snad lepší věci zůstaly mi ležet ve stolku; ale - je těžko býti si sám kritikem, již tam, kde se jedná o píseň, jejíž vznik srostl se životem, a nad to i mně, vzdálenému všeho ruchu literárního, z něhož před dvěma roky náhle jsem byl vytržen, sotva že jsem se v něm rozhlížeti počal“ (TƯMA 1872a: b. s.).

Klatovy na přelomu šedesátých a sedmdesátých let ovšem nebyly, navzdory vzdálenosti od kulturního centra, bílým místem na mapě literárního života. Na zdejším gymnáziu vyučoval spisovatel Alois Vojtěch Šmilovský (1837 až 1883) a mezi studenty, kteří zasílali své příspěvky do almanachů a pražských literárních časopisů, patřili například Josef Thomayer nebo Jaroslav Vrchlický.

1) Životopisná data viz PEŠTA 2008: 1036.

2) Děkuji kolegovi Davidu Frantovi za zapůjčení tohoto pramenu.

3) Konkrétně se jednalo o 46. z Hálkových Večerních písní (HÁLEK 1859: 54).

4) Tůma byl přijat za člena spolku 29. ledna 1870 (UMĚLECKÁ BESEDA 1867-1873).

5) Dochované záznamy dokládají Tůmovu účast na schůzích Literárního odboru Umělecké besedy 12. a 19. března 1870 (UMĚLECKÁ BESEDA 1870).

6) Zápis v kronice gymnázia datuje Tůmovo působení na škole od 20. dubna 1870 (KRONIKA 1865-1914: 47). Za upozornění na tento pramen vděčím Václavu Petrbokovi. 
Tůma se po příchodu do Klatov stal přispěvatelem zábavně-poučného týdeníku Šumavan a jeho vydavatel Maxmilián Čermák (1843-1892) mu ještě v průběhu roku 1871 stihl vydat hned dvě knihy: nejprve epickou skladbu Jaroslav, a poté svazek zmíněných Básní.

Tůmův Jaroslav byl tištěn již v průběhu léta 1871 v Šumavanu, poté knižně u Čermáka a tento náklad byl brzy rozebrán (viz HRDINA 2019: 692). Pro připravované druhé knižní vydání již Tůma našel nakladatele v Praze Františka Augustina Urbánka. V závěru roku 1871 se tak ve srovnání se svými vrstevníky jevil jako velmi úspěšný autor a nakladatel Čermák v inzertní propagaci jeho Básní, která se objevila v Šumavanu, mohl již citovat pochvalná slova, která o Tůmovi otiskly Národní listy a německy psaná Politik (obr. 1). Tyto okolnosti v úhrnu svědčí o ambicích mladého básníka proniknout z územní periferie do centra českého literárního života. Tůma při tom výslovně požádal o posouzení svých veršů, když ve zmíněné předmluvě $\mathrm{k}$ Básním vyjádřil přání, aby nalezly ne snad přímo chválu, ale alespoň „spravedlivé uznání“ (TU゚MA 1872: b. s.).

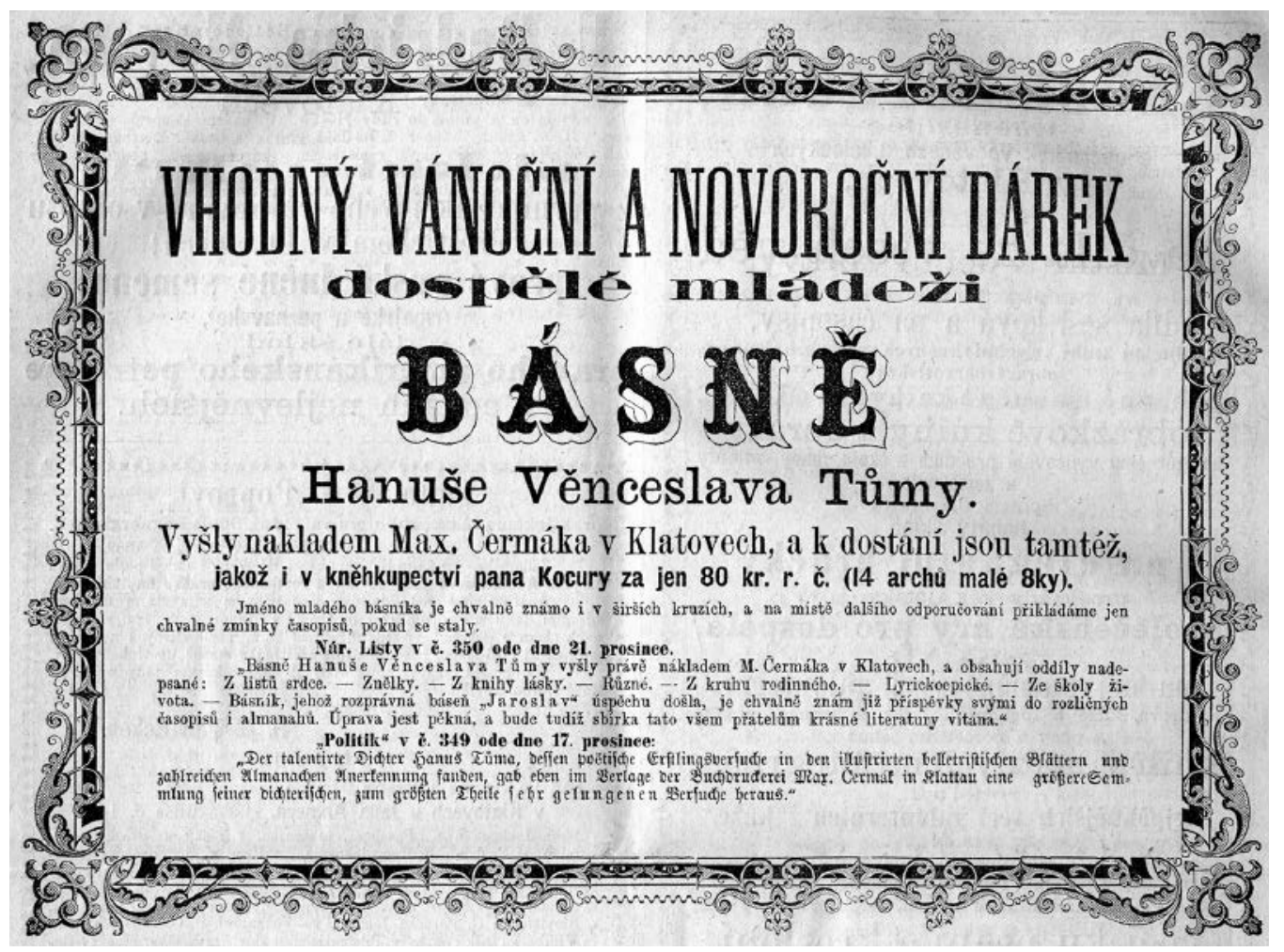

Obr. 1: Inzerát na Tůmovy Básně z 23. prosince 1871 


\section{Referát v Umělecké besedě}

Netrvalo dlouho a v Praze se o posouzení Tůmovy tvorby začalo hovořit, a to přímo na půdě Umělecké besedy. Ačkoli se nejednalo o zvlášt významnou záležitost, v dochovaných protokolech ze schůzí literárního odboru je dokumentována poměrně podrobně. Zápis ze schůze konané 16. prosince 1871 obsahuje poznámku: „P. Klement si přeje, aby se v lit. odb. mluvilo o Tůmově »Jaroslavu«. Nevšímal proti. Hálek pro“ (UMĚLECKÁ BESEDA 1867-1873). Otázku posouzení Tůmových prvotin tedy v literárním odboru nadnesl mladý člen spolku, jinak neznámý student filozofické fakulty Karel Klement, a diskutoval o ní s jiným mladíkem, jímž byl student práv August Vojtěch Nevšímal (1847-1916). Spor o to, zda se o Tůmových básních bude v Besedě oficiálně hovořit, rozhodl předseda odboru Vítězslav Hálek ve prospěch návrhu. Toto rozhodnutí nebylo nijak překvapivé - byl to sám Hálek, kdo v jedné z únorových schůzí roku 1869 spolu s Hostinským navrhoval zavést „rozpravy o nejnovějších plodech literatury české i literatur cizích“ (UMĚLECKÁ BESEDA 1863-1869; srov. PRAŽÁK 1913: 212). Zbývalo jen rozhodnout, kdo se ujme referátu o Tůmově literární prvotině. Touto otázkou se zabýval výbor literárního odboru o dva dny později. Podle protokolu z 18. prosince 1871 měl nejen o Jaroslavu, ale i mezitím do Prahy došlých Tůmových Básních referovat Václav Vlček, a to společně s posouzením básně Otakara Červinky (1846-1915) Roháč z Dubé (UMĚLECKÁ BESEDA 1867-1873).

Pro porozumění tomu, proč byl referát přidělen právě Vlčkovi a jakou váhu jeho soudy $\mathrm{v}$ daném případě měly, je třeba vrátit se v zápisech ze schůzí literárního odboru o několik let zpět a ve stručnosti načrtnout historii kritického posuzování literárních děl v Umělecké besedě. První významnější soud vyslovený zde o soudobých literárních dílech je doložen patrně k 30. září 1865, kdy Karel Sabina $\mathrm{v}$ rámci přednášky o vědecké i krásné literatuře $\mathrm{z}$ předcházejícího roku „charakterizoval“ Hálkova Goara, Jandova Jana Talafúsa z Ostrova a Heydukovy básně, z prozaiků Gustava Pflegera, Karolinu Světlou či Františka Göbla-Kopidlanského. Konkrétní soudy zapisovatel této schůze nezachytil, jisté však je, že v polovině šedesátých let Sabina zastával funkci uměleckého referenta literárního odboru, ${ }^{7}$ která připadla vždy jednomu ze zvolených členů správního výboru. Uměleckým referentem byl Sabina volen opakovaně, jak dokládá například zápis ze schůze 16. listopadu 1867. Tato fakta sice neopravňují k přehodnocení

7) Dokládá to např́iklad zmínka v protokolu ze schůze 30. listopadu 1866 (UMĚLECKÁ BESEDA 1863-1869). 


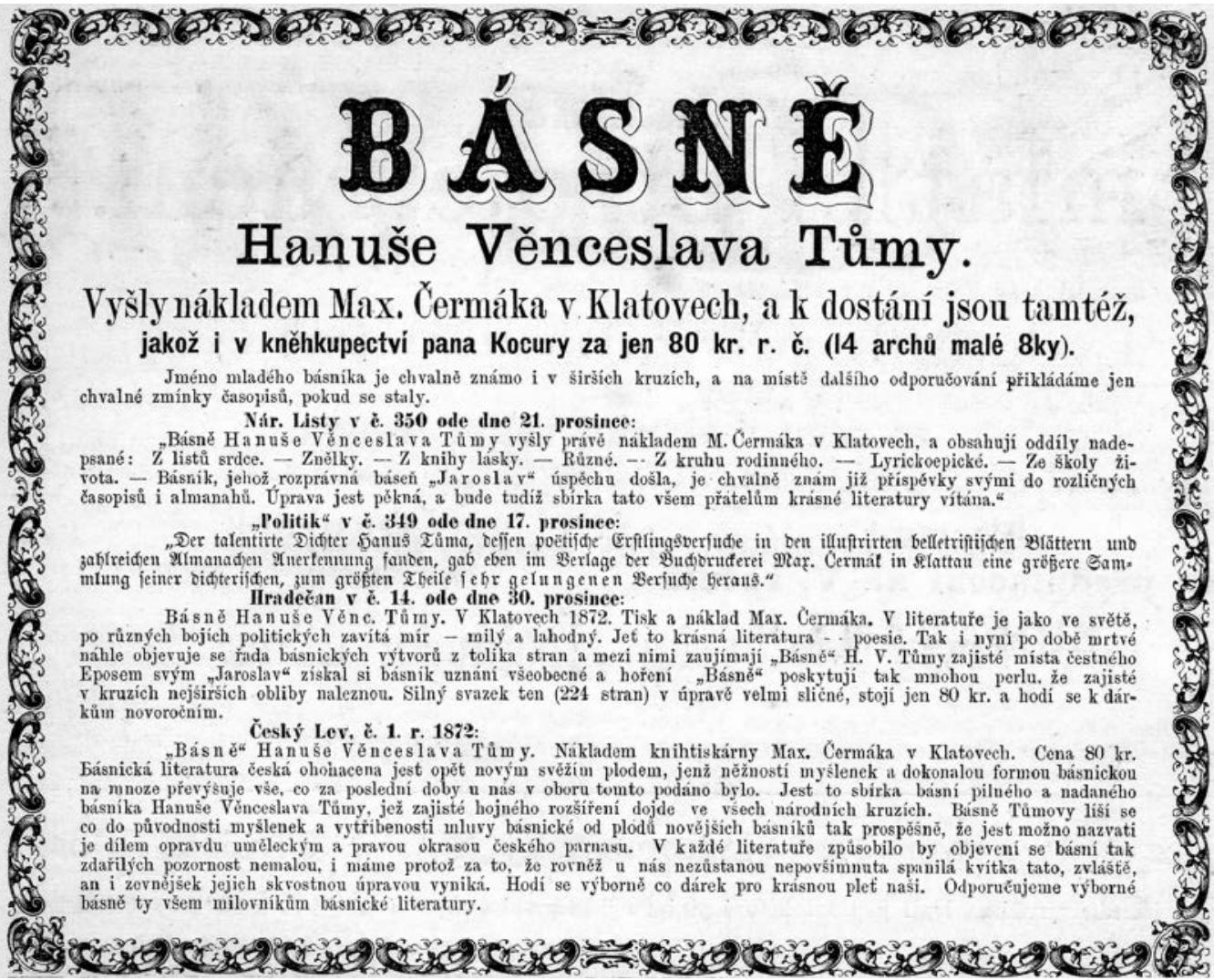

Obr. 2: Inzerát na Tůmovy Básně ze 6. ledna 1872

jeho významu v kritickém poli v šedesátých letech, který byl vnímán jako marginální (POHORSKÝ 1961: 51), dokládají však vnímání Sabiny současníky jako člověka mimořádně kompetentního $\mathrm{k}$ hodnocení literárních děl.

V praktickém provozu literárního odboru se od držitele funkce uměleckého referenta očekávalo, ve větší míře od roku 1867, aktivní posuzování literární produkce a také péče o texty, které do Besedy docházely s prosbou autorů o posouzení. ${ }^{8}$ Sabina zastával pozici referenta do 27 . listopadu 1869, kdy byl na schůzi správního výboru zvolen místopředsedou literárního odboru a uměleckým referentem se místo něho stal Josef Durdík. Již následujícího roku byl ale nově ustaveným výborem na schůzi 16. listopadu 1870 referentem zvolen Václav Vlček, jehož funkce byla potvrzena i o rok později, 4. prosince 1871.

8) Čtení rukopisů a jejich posuzování se kromě Sabiny příležitostně ujímal i jiný velmi aktivní účastník besedního života Jaroslav Goll. 
Vlček, redaktor nedávno předtím založené Osvěty, tedy hovořil o básních mladých literátů z pozice, která i díky předchozím respektovaným držitelům funkce referenta Sabinovi a Durdíkovi dodávala prosloveným soudům punc kritické autority. ${ }^{9}$ Se zadaným referátem si dal načas. O pracích Tůmy a Červinky, k nimž zatím přibyla ještě kniha Josefa Kuchaře (1847-1926) Za soumraku, pojednal na schůzi odboru 13. ledna 1872. Na řadu při tom přišel nejprve Tůma, jehož posouzení dopadlo ten večer zdaleka nejhưr̆ - ani v dosavadní historii besedních schůzí bychom nenašli mnoho tak př́krých soudů, jaké Vlček vyslovil o Tůmovi a jeho básních. Byly ovšem odůvodněny citacemi z díla a věcně proti nim bylo lze sotva co namítat.

Vlček vytýkal Tůmovým Básním vnitřní i vnější nepravdivost, vyjadřování povrchních citů, nesrozumitelnost a gramatické nešvary - celkem soudil: „Neschází-li mu vůbec nadání básnického, schází mu ještě průprava“ (UMĚLECKÁ BESEDA 1867-1873). ${ }^{10}$ Pokud jde o Jaroslava, Vlček připomněl, že Tưma v něm napodobil epickou formu Rukopisu královédvorského, děj básně je prostý, podaný bez zápletky a zauzlení, a autorovi se nepodařilo vtělit v ni „staré názory“, jak předesílal v předmluvě. Také o Kuchařových básních Vlček poznamenal, že jsou napodobením - v tomto případě Hálkových Večerních písní. Přestože se Kuchař podle Vlčka ještě nedobral individuálnosti, bylo na rozdíl od Tůmy v jeho případě možné hovořit o „skutečných básních či v sobě ukončených celcích“. Konečně u Červinky Vlček poukázal na napodobování Byrona a vedle řady nedostatků nalezl v jeho práci, na rozdíl od prací obou zmíněných vrstevníků, také chvályhodné prvky: hluboké myšlenky, hlubokou fantazii, vytříbený jazyk (IBID.). ${ }^{11}$

Živá diskuse po Vlčkově referátu, jíž se vedle Hálka a Nevšímala zúčastnili například Josef Barák, Ladislav Quis a František Dvorský, se postupně stočila k problému „lehkovážné kritiky listů venkovských“ (IBID.) - míněno nekritičnosti mimopražských novin a časopisů při posuzování literatury. Takové zaměření debaty je překvapivé, lze je však vysvětlit širším kontextem kritického přijetí Tůmových prvotin. $K$ výše zmíněným pochvalným soudům o Tůmovi a jeho básních, otištěným v Politik (17. prosince) a Národních listech (21. prosince), totiž v průběhu následujících týdnů přibývaly již podrobnější, velmi kladné až oslavné soudy v dlouhé řadě mimopražských periodik: Hradečanu (30. prosince), Českém Lvu (4. ledna), Horymíru (5. ledna), Táboru (6. a 20. ledna),

9) Až do července 1872 nebyl Sabina věrohodně usvědčen z konfidentství.

10) Cituji zde i dále z protokolů s vědomím, že konkrétní formulace se leckdy lišila od znění v zápisu. Protokoly z jednání byly ovšem pravidelně schvalovány na následující schůzi odboru s možností korektur.

11) Několik dní před konáním této schůze byla v Květech otištěna kritika Červenkových básní (ANONYM $1872 b$, viz dále), která uvedené pozitivní charakteristiky nezmiňuje. 
Dělnických novinách (6. ledna), Našinci (12. ledna), Ohlasu od Nežárky (13. ledna) a Moravské Orlici (19. ledna). Jako př́klad z tohoto spektra ohlasů postačí uvést noticku z Českého Lva: „Básně Tůmovy líší se co do původnosti myšlenek a vytříbeností mluvy básnické od plodů novějších básníků tak prospěšně, že jest možno nazvati je dílem opravdu uměleckým a pravou okrasou českého parnasu. V každé literatuře způsobilo by objevení se básní tak zdařilých pozornost nemalou [...]“ (ANONYM 1872a: 3).

Ačkoli Vlček s pochvalnými soudy tohoto druhu ve svém referátu nepolemizoval, přítomným posluchačům byly alespoň některé $\mathrm{z}$ nich velmi pravděpodobně známy a referát $\mathrm{v}$ Umělecké besedě i následnou diskusi o nekritičnosti venkovských periodik zřejmě vnímali na jejich podkladu. Diskuse vyústila v návrh Františka Haufa, „aby básníci se vyzvali, by si dali rukopisy posoudit od besedy umělecké“ (IBID.). Návrh podaný v rámci diskuse o literárních novinkách pochopitelně nebyl určen k okamžitému hlasování a literární odbor ani později nedospěl k explicitní výzvě tohoto druhu, která by byla adresována mladým autorům. Debata o venkovských listech se však v následujících měsících, jak uvidíme dále, rozšírila ze spolkových místností do širšího prostoru.

\section{Literární hlídka Květů}

Zatímco na půdě Umělecké besedy byl na počátku roku 1872 oficiální kritickou autoritou Vlček, $v$ prostoru českojazyčných periodik měl největší autoritu k souzení - alespoň u nejmladších autorů, usilujících vstoupit na literární pole - Vítězslav Hálek. Jím vedené Květy byly v Čechách na přelomu šedesátých a sedmdesátých let centrální beletristickou platformou par excellence, listem co do prezentace poezie prestižním ve srovnání s dalším pražským časopisem, který věnoval pozornost beletrii, Světozorem. Pro mladíky šplhající na parnas bylo prvořadým cílem mít $\mathrm{v}$ Květech otištěné verše, zpravidla se přitom dočkali nejprve Hálkových glos, poprrípadě i rady v rubrice Dopisy zaslané redakci. Hanuš Věnceslav Tůma byl jedním z těch, kteří se na konci šedesátých let pokusili proniknout na stránky Květů bez úspěchu. ${ }^{12}$ Své jméno spatřil v Hálkem redigovaném časopisu až 25. ledna 1872, kdy se v literární hlídce objevil posudek jeho Básní.

12) Soudíme tak podle výroku z pozdější polemiky, adresovaného pravděpodobně Hálkovi: „Podával jsem ostatně skromně svoji »sbírku« [tj. Básně] do rukou obecenstva, sbírku, jejíž nejlepší práce nadarmo se dodělávaly uveřejnění, uspány jsouce v sen spravedlivých v redakci Vaší“ (TU゚MA 1872b: 48). 


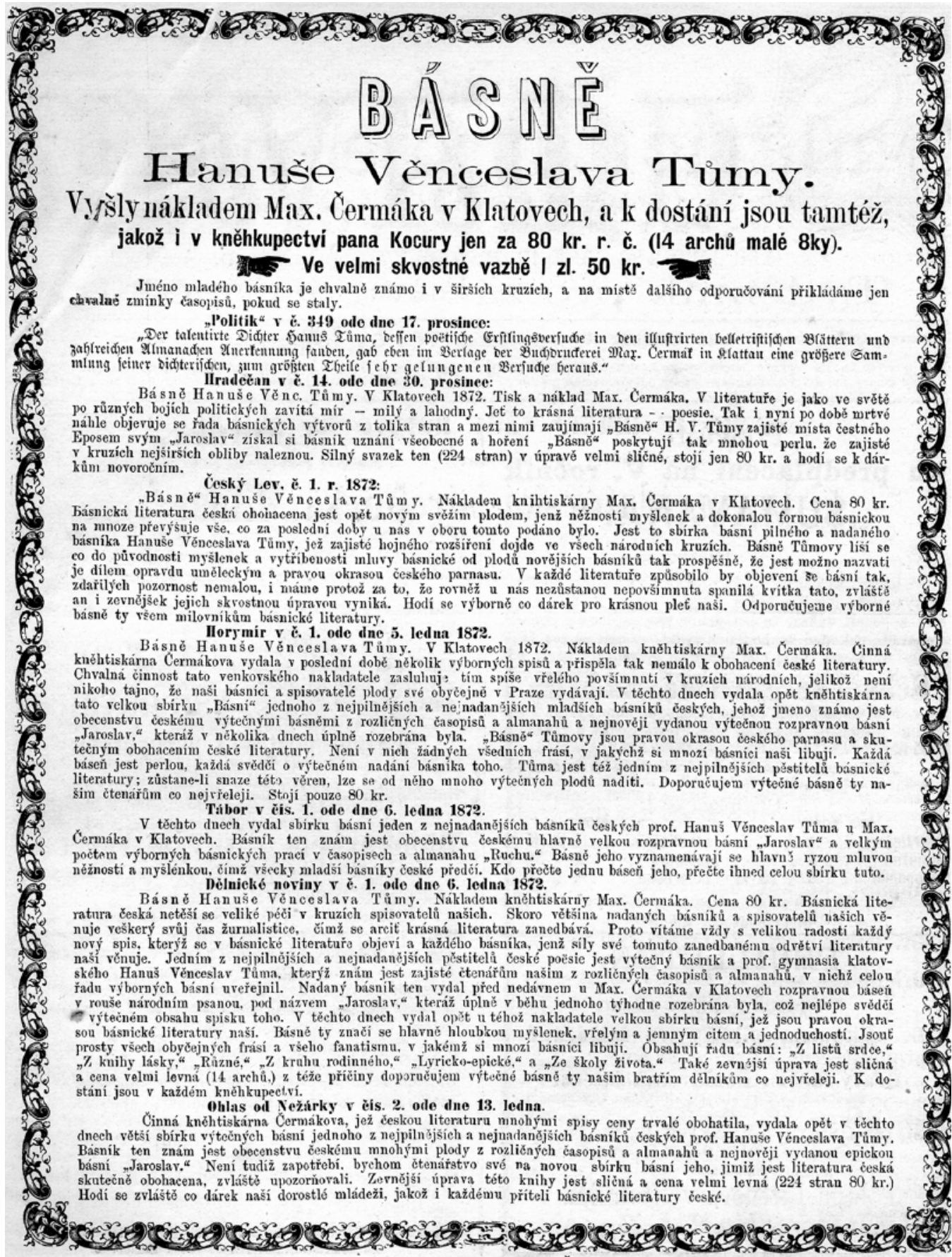

Rychlotiskem, nákladem a redakcí Max. Čermáka $\mathrm{v}$ Klatovech.

Obr. 3: Inzerát na Tůmovy Básně z 20. ledna 1872 
Tůma, jehož básně byly veskrze kladně přijaty v mimopražských periodikách, je v anonymním textu otištěném v Květech vylíčen jako nekritický psavec nedbalé formy, který si bez výčitek svědomí vypůjčuje myšlenky od jiných básníků. Posudek je uzavřen větou: „Takovýchto básní mohl by vydati deset svazkủ do roka, a ještě by nic nevydal. Podobné básnění věříme, že ho arci neunaví, ale básněním to není" (ANONYM 1872c: 31). Ve srovnání se souputníkem Červinkou dopadl Tůma mnohem hůr̆. Recenze Červinkovy básně v předposledním čísle Květů se sice nesla rovněž v silně negativním duchu, ale Červinka v ní byl alespoň označen za „talent nadějný, jehož vítáme v literatuře“ (ANONYM 1872b: 15). O Hálkově autorství obou recenzí se nepochybuje, ${ }^{13}$ jejich dílčí shody s obsahem Vlčkova referátu (zčásti přejatá argumentace; citace týchž míst z Tůmova textu) lze vysvětlit přítomností redaktora Květů na schůzi literárního odboru. Zatímco Vlček však pojednal o Tůmově tvorbě se vší vážností - už kvưli možné přítomnosti samotného autora, jenž byl stále členem Umělecké besedy -, Hálkův posudek byl psán výsměšným tónem, „cestou příkladů“ (ANONYM 1872c: 31), resp. více méně vtipně glosovaných úryvků z textu namísto zevrubnějšího, pečlivě argumentovaného rozboru, jehož se v Květech dostalo Červinkovi.

Nezdařilé práce literárních začátečníků měl Hálek ve zvyku traktovat s posměchem nejen ve zmíněné rubrice Květů Dopisy zaslané redakci, ale i mimo ni v publicistice z pozdější doby. Například článek Klasikové z venkova uvedl slovy: „Dělám si pro sebe malé klasobraní z oněch poetů, kteří ve venkovských listech vylévají v divných rýmech a vůbec v divných formách upřímné city své“ (HÁLEK 1874: 1). Cíl zde byl srovnatelný s Tůmou - začínající literáti z mimopražského prostředí - a technika táž: ironické glosování citátů z jejich textů. Tůmův případ byl výjimečný tím, že Hálek uplatnil zvolený přístup ve formátu standardní recenze. Argumentace zpochybňující kvalitu Tůmových Básní byla sporá a shodou okolností táž, kterou svého času zamířil Jan Neruda na první knihu Hálkovy poezie, Večerní písně - nepůvodnost myšlenek a zbytečně velký rozsah knihy (viz NERUDA 1957: 48-49). Rozdíl mezi oběma případy je však zřejmý na první pohled: zatímco Neruda na sklonku padesátých let promlouval v posudku Večerních písní k Hálkovi jako svému souputníku na poli poezie, Hálek užívající obdobné argumentace v roce 1872 se obracel k Tůmovi - podobně jako jeho kolega z Umělecké besedy a redaktor Osvěty Vlček - z pozice strážce literárního pole, autoritativního rozhodce o tom, co je literaturou, a co není.

13) Viz JEŘÁBEK 1959: 103-104. Již Jan Voborník zařadil oba referáty do 4. dílu Hálkových sebraných spisů (1907). 
Již dva dny po zveřejnění inkriminovaného posudku se rozhořčený Tůma dostavil do redakce klatovského Šumavana s apologií nadepsanou Panu literárnímu referentovi „Květů“! Ohradil se v ní proti posměšnému traktování svého díla a s nemenším vtipem reagoval na výtky uvedené anonymním recenzentem. Podotkl přitom, že „úloha kritikova není žádná komedie“, a adresátovi své obrany vzkázal, že způsobem, jakým bylo pojednáno o jeho básních, „velmi snadno bylo by každému, za příkladem Vaším tak mnohé věci i »čelnějších" našich básníků, ba velikánů poezie světové uvésti na směšnou stránku a udělat $\mathrm{z}$ nich paskvil“ (TƯMA 1872b: 47-48). V obhajobě svých Básní Tůma poukázal také na to, že se jednalo o juvenilní tvorbu, a poučoval referenta Květů s narážkami na dílo Vlčkovo, Nerudovo a Hálkovo: „Konečně si dovoluji podotknout, abyste byl dobře pamětliv toho, že před »Eliškou Přemyslovnou« atd. dávaly se »Šachy«, že před »Knihami veršů «yšlo »Hřbitovní kvítí«, ba že »Vukašín«a »Catilina« dávaly se teprve po »Záviši z Falkenštejna“ (IBID.: 48). Také tato připomínka patrně měla odůvodnit požadavek, aby kritika byla shovívavá k dílům začínajících literátů.

Závažnější výroky přinesla apologie začínajícího básníka o problému obsahové původnosti literárního díla. Tůma odmítl výtky (činěné mu Hálkem) vykrádání či otrockého napodobování jiných básníků a připomněl, že „se nebralo za zlé tomu, kdo napodobil [V]ečerní písně “, ${ }^{14}$ ale především, narážeje již zjevně i na Hálka, že se běžně přijímá „počínání si našich Shakespearův, Heinův, moderních francouzských lyriků aj. en miniature, kterým se napodobování pokládá za geniálnost, a oni tomu věři sami, nedělajíce si z toho žádného svědomí" (IBID.: 48). Navazující apelativní pasáž Tůmovy obrany přešla již v přímý útok na Hálka, když zpochybnila jeho pozici nejen jako respektovaného básníka, ale i hodnotitele literárních děl a provozovatele určitého typu kritické praxe: „Ukažte nám génia v literatuře naší opravdového a samostatného, jenž by byl schopen svými plody zarazit básnickou školu a ustálit nějaký směr, a já, však ne já, dvacet a sto jiných, kořit se mu budeme a těšit se $z$ toho velice, jestli ze záře jeho dostane se nám nějakého paprsku. Avšak libovolně stavět sebe a jen sebe za nezvratné, samospasitelné měřítko, to je př́lišná domněnka o sobě samém, jejíž oprávněnost potřebuje teprve důkazů“ (IBID.: 48).

Kromě Tůmovy adresné polemiky s Hálkem začal Šumavan tisknout také seriál anonymních článků Literární kritika a kritikářský protektorát, jehož autorem byl, soudě podle kontextu uveřejnění i explikace problému kritického autoritářství, ${ }^{15}$

14) Touto narážkou mohl mít Tůma na mysli svého souputníka Josefa Kuchaře, jejž za napodobitele Večerních písní označil Vlček. Naznačoval by tím, že je obeznámený s děním v Umělecké besedě.

15) Autor článku si vytkl za cíl pojednat o nedostatcích literární kritiky bez bázně před „jednotlivci, kteří [...] mají se 
rovněž Tůma. Vlastní případ začínajícího literáta dotčeného kritikou se přitom pokusil traktovat jako problém celého literárního pole, v němž je vytyčen protiklad mezi centrem literárního života, které představuje Praha, a literární periferií. Tůma uznával, že Praha je po právu také „sídlem kritiky“, za chybu ale považoval, je-li kritická aktivita soustředěna v rukou několika jednotlivců (ANONYM 1872d: 68). Připomněl v této souvislosti Chmelenského Slovo o kritice a v jeho intencích uvažoval o úloze kritika: „Kritik jest soudcem, přísným sice, ale přívětivým a zdvořilým, a co takový hledí $\mathrm{k}$ spisu, a ne $\mathrm{k}$ prátelství, známosti, libosti a podobným věcem, z kterých vzniká kritikářský monopol“ (IBID.: 91). Takový stav, jejž Tůma označil „absolutismem v literárních poměrech“, byl podle něho „př́ičinou, že podporují se jenom firmy literární, že vliv mají velký na kritiku naši osobní známosti, libost či nelibost kritikova, známost či neznámost jména spisovatelova, a konečně - někdy i místo, v kterém kniha vydána byla, což jest všecko nejlepší. A tak venkovští spisovatelé i nakladatelé přijdou velmi zkrátka, třebas měli nejlepší vůli a produktivností se i těm městským rovnali, a to vše proto, že jsou neodvisli (IBID.: 39).

\section{Literární rozhled Osvěty}

Tůma se ve své apologetice vyslovil o českém literárním milieu, a zejména o kritickém posuzování literární produkce. Obranné texty, které by při své dikci sotva mohly být publikovány v pražských periodikách, byly zřejmě hořkou pilulkou nejen pro atakovaného Hálka, ale i prvního referenta o Tůmových prvotinách Vlčka, a provokovaly k replice. Na stránkách Vlčkovy Osvěty se jí zhostil Ferdinand Schulz - švagr majitele dotčených Květů Eduarda Grégra -, jenž posunul poměr kulturního centra $\mathrm{k}$ Tůmovi a jeho básním na rovinu pamfletu.

Schulz ve svém posudku odepřel Tůmovi „upřímnou uměleckou snahu“ a odmítl o jeho básních vůbec psát kritiku, „nebot’ ta vyžaduje přece jakousi míru myšlenkové neb formelní ceny při svém předmětu “- místo toho se rozhodl podat „pouhou zprávu o literárním plodu, způsobeném na ponětích tak velice chybných a domáhajícím se rozhodnou vytrvalostí přece jakési veřejné platnosti“(SCHULZ 1872: 317). Místo avizované „pouhé zprávy“ však Schulz přece jen napsal kritickou

za výhradně povolané, za poslední autoritu, od níž není žádného odvolání“ (ANONYM 1872d: 38), a argumentaci namířil proti „těm, kdož u vesla sedí“, proti „zjevnému odbývání, patrnému vylučování neznámého z činnosti literární“ - míněno spisovatele „neznámého v kruzích širších osobně“ (IBID.: 39). 


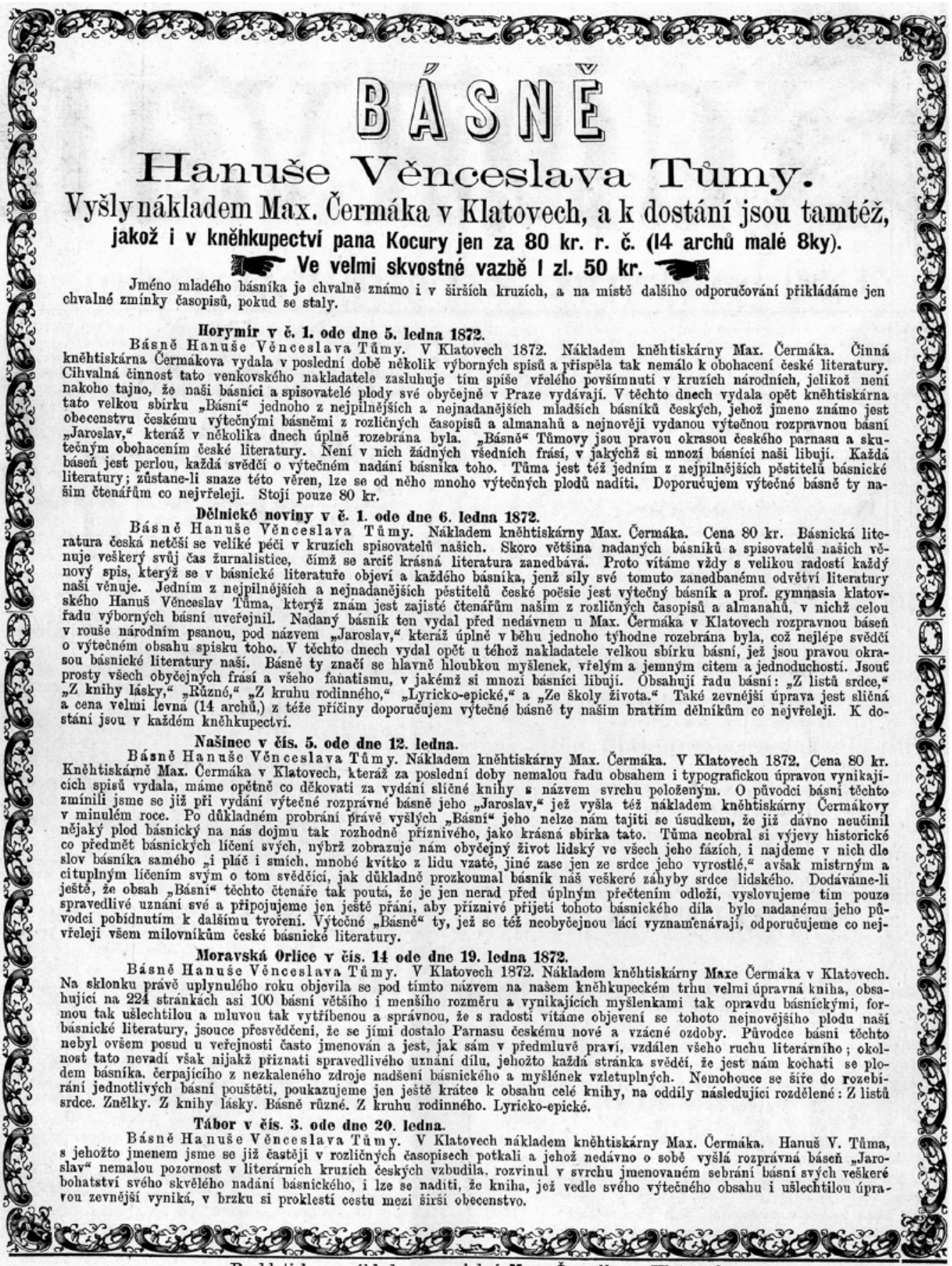

Rychlotiskem, nákladem a redakcí Max. Čermáka v Klatovech.

Obr. 4: Inzerát na Tůmovy Básně ze 3. února 1872 
úvahu, v níž zopakoval Vlčkovy argumenty proti Tůmovým Básním (nepravdivost, nepřirozenost citu, mluvnické chyby, nedbalá stylizace), a nadto vylíčil Tưmu jako nemorální osobu nepravdivých citů, pohrávající si s publikem. Schulzovým kritickým měřítkům nevyhověl ani Tůmův Jaroslav, v němž postrádal „samostatnou, tvořivou sílu básnickou, plnou vlastních citů a názorů“ - přístup autora popsal jako „opisování zvláště typických obrazů básnických a stylistických obratů z nejstarších památek naší literatury do nějakého nynějšího vypravování“ (IBID.: 319). ${ }^{16} \mathrm{~V}$ závěru své úvahy si Schulz neodpustil konstatování, že Otakar Červinka vstupuje do české literatury mnohem štastněji.

Tůma odpověděl také na Schulzův pamflet. V textu otištěném v Šumavanu na konci března zaútočil nejen na Schulze, ale nepřímo i na Osvětu a jejího redaktora Vlčka, když odmítl mluvit dále „s lidmi, kteří, chtíce jiným pomáhat, překrucují více a chápají hůře, nežli pomocní a vždy úslužní jejich přátelé, a zbavivše se vší slušnosti, chtějí takovými manévry šiřit "osvětu “" (TŮMA 1872c: 135-136). Ironicky se vyjádřil o recenzování formou širších rozhledů po literatuře, zavedené v této revui: „Z čtenář mých básní neztřeštil se posud nikdo; přihodilo-li se to panu Ferd. Schulzovi, tut je k politování on a ne já, a literatura naše o jedno "slovesné znázornění» důkladného "rozhledu « bohatší “ (IBID.: 136). Také v tomto případě byla Tůmova ironie reakcí na fakt, že recenzent neposoudil jeho Básně korektně. Schulz se zmínil vlastně jen o dedikaci sbírky, přičemž nestoudně překroutil její smysl. Proti tomu se Tůma ohradil a v nadsázce vyslovil obavu, že poté, co proti Schulzovi, jenž přispěchal na pomoc „kritikovi“ Květů (tj. Hálkovi) a věnoval polovinu referátu předmluvě a dedikaci, by on před kritikou „musel hájit potřetí snad titul, jméno na něm aneb i obálku svých »básní«, a naproti čtvrtému snad i péro, kterým [...] psal“ (IBID.: 136).

\section{Cézura mezi kulturním centrem a periferií ve světle Tůmovy aféry}

Otevřený dopis Ferdinandu Schulzovi byl Tůmovým posledním slovem ve sporu, jehož výsledek známe: autor vykázaný třemi významnými kritiky za hranice literárního pole nakonec na další tvorbu rezignoval. Průběh tohoto sporu, a zejména jeho okolnosti však ukazují, že kvalita Tůmova díla zde nebyla jediným,

16) Z odstupu se jeví až kuriózní, že na stránkách Osvěty bylo odsouzeno dílo úzce svázané s Rukopisem královédvorským coby národoveckou modlou par excellence. Tůma se v tomto směru satisfakce nakonec dočkal, ovšem až o pět let později v Muzejníku z pera Elišky Krásnohorské (viz HRDINA 2019: 709). 
a zřejmě ani hlavním měřítkem. Nemenší význam měl fakt, že autor pronikal do prestižního pole básnické tvorby z mimopražského prostředí, ve kterém se etabloval po odmítnutí hlavní posvěcující instancí v dané oblasti, jíž byly Hálkovy Květy. Případ Tůmových prvotin dokumentuje potenciální sílu literární periferie hned v několikerém ohledu. Předně poskytla Tůmovi publikační prostor, který mu byl v kulturním centru odepřen (konkrétně Šumavan a Tábor). Našel zde také nakladatele ochotného vydávat jeho díla, a to opakovaně. O jeho díle bylo rozšířeno (povětšinou ve formě oznámení vycházejících z podkladů, které nakladatel zaslal redakcím) množství pozitivních soudů, jež byly následně využity při inzertní propagaci (vždy s uvedením jména periodika, které knihu doporučuje - viz obr. 1-4). To vše současně ukazuje, že při obhajobě svých zájmů dokázali kooperovat nejen pražští, ale i venkovští autoři, redaktoři, nakladatelé a vydavatelé.

Zvláštní pozornost si zaslouží Tưmovo poukázání na „nezávislost“ periferního prostředí, které mu umožnilo šírit též apologetické texty, ${ }^{17}$ na pražském kulturním centru. $Z$ tohoto úhlu pohledu se v průběhu sporu o Tůmovo dílo literární periferie ukázala být místem, kde je oslabena strukturální cenzura panující v poli, ${ }^{18}$ kde se lze vyjadřovat volněji a snáze tak zpochybňovat řád, střežený představiteli kulturního centra a jeho institucemi. Významným zásahem do tohoto řádu, do existujícího poměru sil mohl být v návaznosti na průběh sporu návrh, k němuž dotčený Tůma ve své apologetice dospěl, a sice spojení mladších spisovatelů při obhajobě svých zájmů a soustředění sil v některém ze zavedených časopisů, který by měl jednak prezentovat jejich práci, jednak ji hájit proti eventuálním „přehmatům a křivdám“ (ANONYM 1872d: 91). Tůma se s tímto návrhem obracel na další mladé autory, kteří paralelně s ním vstupovali na literární pole a podobně jako on pocitovali nepřízeň klíčových posvěcujících instancí. Konkrétně se mohlo jednat například o „jihočeskou omladinu“ - skupinu studentů z Písku, Vodňan, Českých Budějovic, Jindřichova Hradce a Tábora, z nichž nejaktivnější byli Josef Kálal, František Herites, Otokar Mokrý, Jan Dunovský a Josef Holeček (srov. PAVLÍČKOVÁ 2006: 56n). Také v tomto okruhu nejmladších literátů, kteří v prosinci 1871 dokončili redakční přípravu

17) Tůmův článek Literární kritika a kritikářský protektorát přetiskl kromě Šumavana také plzeňský politický list Český Lev.

18) Podle Pierra Bourdieua v literárním poli existuje strukturální cenzura, jíž se „musí podřídit každý producent symbolických statků, nevyjímaje oprávněné mluvčí, jejichž autoritativní promluva je více než kterákoli jiná podřízena normám oficiální přípustnosti“ (BOURDIEU 2014: 104). Naopak ty, kdo v rámci daného pole působí v podřízených pozicích, podle Bourdieua „odsuzuje cenzura bud’ k mlčení, anebo ke skandální otevřenosti“ (IBID.: 104). 
almanachu Anemonky a našli pro něj nakladatele rovněž ve Františku Augustinu Urbánkovi (jenž slíbil znovu vydat Tůmova Jaroslava), panovala určitá nespokojenost se stávajícími poměry.

Redakční kruh v úvahách předcházejících uveřejnění Anemonek (1872) kalkuloval při výběru přispěvatelů mj. s tím, že kritika bude benevolentní $\mathrm{k}$ autorům, jejichž jména jsou vesměs neznámá. V dopisu z 8. června 1871 Jan Dunovský předestřel Josefu Holečkovi jeden $z$ důvodů, proč by do almanachu měli přispět pouze Jihočeši: „Podržíme-li u sebe, budeme se moci opříti mnohému dryáčnictví, kmotříčkářství a darebáctví v české literatuře - můžeme býti pěknou opozicí někdy“ (DUNOVSKÝ 1871). Zmíněného „dryáčnictví, kmotříčkářství a darebáctví" si nejstarší z Jihočechů, Kálal a Dunovský, povšimli velmi brzy po příchodu do Prahy na studia a po zapojení do spolkového života. ${ }^{19}$ Když se Josef Holeček v roce 1886 ohlížel za prvními krůčky této neformální skupiny autorů na poli literatury, vzpomínal na jejich boj proti „starým“ v Praze, již „nechtěli a nechtěli je uznávati a př́spěvky jejich do sloupců svých časopisů přijímati“; jako „katana nejmladšího spisovatelstva“ vnímali mladí Vítězslava Hálka, jinak ovšem okouzlujícího básníka, kterého shledali hodného napodobení (HOLEČEK 1886: 1).

Holeček v citované vzpomínce sice přijal s pochopením Hálkovu přísnou kritiku Anemonek jako náležitou a podržel jejího autora v uctivé vzdálenosti od pražské koterie, dochovaná korespondence redakčního okruhu almanachu z této doby však svědčí o jiném bezprostředním vnímání Hálka ze strany mladých na počátku sedmdesátých let. Jan Dunovský ve výše citovaném dopisu vylíčil také Kálalův výstup ve studentském spolku Slavia, kde probíhaly podobně jako v Umělecké besedě rovněž referáty o literatuře: „Nedávno vystoupil Kálal s kritikou o Hálkově básni Děvče $z$ Tater. Sebral jej rozkošně. Pro posluchače to bylo něco neslýchaného. Já si myslím: Ubožáci! nemohou snésti čerstvý vzduch! Učinilo to přece jakousi epochu. Že se v literním světě o tom úplně mlčí je $z$ jedné strany př́ičina ta - že Slavia je vưbec ve vážnosti, z druhé strany, že Hálek je vůbec zbožňován. O pitomci! Jen se klaňte modlám! Uctivost k němu roste s jeho břichem“ (IBID.). Tưmova polemika s představiteli pražské kritiky, nabývající rysy aféry, tedy nebyla jediným dobovým projevem „skandální otevřenosti“ (viz zde pozn. 18) ze strany literátů nacházejících se v podřízeném postavení v poli, jejímž cílem bylo zpochybnit zdánlivou nedotknutelnost Hálkova díla. ${ }^{20}$

19) Kálal a Dunovský docházeli také do Umělecké besedy, kde mj. vyslechli zmiňovaný Vlčkův referát o Tůmovi.

20) Oba uvedené př́ílady lze doplnit k Jeřábkově polemice s omylným tvrzením F. X. Šaldy, že „celkem prožil Hálek celý svůj básnický život bez kritiky“ (JEŘÁBEK 1959: 100). 
Zatímco Neruda ve zmíněné kritice Večerních písní upozorňoval Hálka na počátku jeho literární dráhy na nedostatečnou autokritiku v důsledku přátelských vazeb (viz též JEŘÁBEK 1959: 101), Tůma na počátku roku 1872 traktoval téhož autora, ovšem již jako čelného reprezentanta české básnické produkce, jako součást pražské koterie, ztělesnění „absolutismu v literárních poměrech“, a jeho básnické dílo v důsledku toho jako unikající kritice, jaká by byla adekvátní významné pozici, kterou autor zaujímal v literárním poli. ${ }^{21} \mathrm{~V}$ pozadí českého literárního života již v té době zřejmě klíčil pokus o korekturu tohoto stavu, který na podzim téhož roku nabyl podobu Durdíkovy kritiky Hálkových básní $V$ př́rodě (1872). Pro analýzu tohoto významného kritického vystoupení zde není prostor, je však záhodno věnovat pozornost ještě Hálkově reakci - již mimo sféru anonymního vystupování - na Tůmovu aféru, během níž byla zpochybněna jeho autorita na poli literární kritiky.

\section{Hálkova kampaň proti venkovským časopisům}

Pozice Vítězslava Hálka v českém literárním milieu se krátce po skončení Tůmových polemik s pražskými kritiky shodou okolností podstatně změnila. Náročně vedené Květy sice přinášely kvalitní básnickou produkci, měly však nízký počet odběratelů. Stálý finanční schodek podniku tak na jaře 1872 vyústil v krach dalšího časopisu, který Hálek vedl, a kritický arbitr, k jehož soudu se upínali autoři vstupující na pole poezie, tak přišel o klíčovou platformu, která mu umožňovala „střežit“ vstup na pole básnictví. Prostor plnící tento účel se Hálek pokusil získat v Národních listech, do jejichž redakce nastoupil po krachu Květů, avšak neuspěl - majitel novin Julius Grégr mu psaní kritik ani divadelních referátů nepovolil, protože tuto agendu zde již měl na starosti Jan Neruda. ${ }^{22}$ Hálek však prostor vymezený Grégrem dokázal využít a zakrátko se k ovlivňování literárního pole podle svých potřeb vrátil, byt๋ v jiné formě, než bylo pravidelné referování o literárních počinech nováčků.

21) Hálkovy epické skladby ovšem kritice podrobovány byly, a to i na půdě Umělecké besedy - např́klad Ferdinand Schulz zde již v roce 1869 konstatoval, že Hálek „epikem nebyl a nebude“ (cit. podle PRAŽÁK 1913: 212).

22) Okolnosti zániku Květů vylíčil ve svých pamětech Servác Heller: „Dr. Julius Grégr, jehož zvláštním miláčkem Vítězslav Hálek byl, pravil mu po kamarádsku: »Tak Viktore, vyber si, co u nás chceš dělat. Ale moc si toho pro začátek neber.« Hálek odpověděl, že by snad mohl zase, jako na počátku Národních listů, psáti divadelní referáty a literární kritiky, jež se dají psáti doma. Ale na to nebylo ani pomyšlení, ježto zde veslo tř́mal Neruda, s nímž se nedalo zahrávat. Dr. Grégr učinil ještě několik pokusů, aby se ukázalo, má-li snad Hálek pro nějaký určitý obor speciální nadání, ale bez úspěchu: Hálek pro vlastní denní, redakční práci žurnalistickou ani chuti ani smyslu neměl, a takž nezbylo, než uložiti mu psaní volných črt a rozprav pro fejeton“ (HELLER 1916: 104). 
V průběhu jara a léta 1872 se pozornost české veřejnosti upínala jinam než k poměřování sil v literárním poli. Období jara vyplnil ruch kolem chabrusových voleb, na konci května se na Prahu od jihozápadu přivalila ničivá povodeň. Klid letních měsíců, kdy se neschůzovalo ani v Umělecké besedě, narušil otřes celé kulturní sféry způsobený prokázáním Sabinova konfidentstvíi. ${ }^{23}$ Teprve na konci léta, kdy Sabinova aféra kulminovala, tak měl Hálek čas a příležitost rozběhnout několikaměsíční kampaň proti mimopražským časopisům a nakladatelským podnikům, která upozorňovala na nízkou úroveň jejich produkce. V kontextu našeho pojednání se tato kampaň, jejíž přínosy byly již pojmenovány (viz např. JEŘÁBEK 1959: 102, HAMAN 1999: 42), jeví jako vystupňovaná kritika mimopražského literárního milieu, které umožnilo nepř́liš nadanému Tůmovi nastoupit na cestu za uznáním a domáhat se ho poměrně razantně také u kritických instancí činných v centru české kultury.

Na Tůmovu aféru Hálek narážel ve druhém dílu seriálu Naše literární trhy ze 30. srpna 1872. V nejčernějších barvách v něm vylíčil nízkou úroveň literární produkce českého venkova a zmínil se mj. o jejím vychvalování formou reklamy: „Již to jest úkazem nadmíru zvláštním, že ve venkovských listech (s malými čestnými výminkami) nečteme úvahy jiné, leč takové, které jim dotčení nakladatelé zašlou sami a kteréžto úvahy jsou pak skorem ve všech listech doslovně stejny" (HÁLEK 1872a: 1). ${ }^{24}$ Hálek také připomněl, jak venkovské prostředí obvykle reaguje na kritiku přicházející z centra: „A pak, když lidé jemnějšího vkusu počnou se za podobnou literaturu i za podobnou reklamu styděti a veřejně to řeknou: ti páni na venku a v předměstích unisono spustí na pražskou kritiku, že prý by nejraději všecko měli jen v Praze a co nepochází od spisovatelů pražských, pražská kritika že prý z úmyslu chce utopiti aneb umlčeti“" (IBID.: 1). Na venkovská periodika Hálek udeřil i ve čtvrtém dílu seriálu ze 6. září, když konstatoval, že právě venkovské listy se až na čestné výjimky vyznačují „patrným nedostatkem estetické rozvahy“ a „stávají se namnoze skladištěm reklamy až nestydaté" (HÁLEK 1872b: 1).

Článek Naše literární trhy měl z hlediska reflexe celé oblasti souzení o krásné literatuře zásadní význam. Hálek v něm sice konstatoval potěšitelný stav české kritiky posledních let, navrhl však v aktuální situaci přehodnotit pravidlo platné od dob Chmelenského, podle něhož si kritika neměla všímat nepodařených

23) Hálek, jenž se účastnil pověstného „národního soudu“ nad Karlem Sabinou, byl s událostí nepřímo spojen i jinak nedávno předtím se za Sabinu zaručoval u soudu ve Vídni, jehož rozhodnutí se ve světle odhaleného konfidentství jevilo jako nespravedlivé (KOVAŘÍK 2010: passim).

24) Analýza inzerce Tůmových Básní v Šumavanu a dalších časopisech, na jejíž provedení zde není dostatečný prostor, by potvrdila platnost Hálkova tvrzení i pro tento případ. 
prací: „Kritika má znáti literaturu v celé její souvislosti, a tedy má znáti také to, co jsme charakterizovali jakožto prázdné, nezáživné a nechutné. A jakož krásné plody ducha nazve jmenem pravým, má i nedozrálá tato pouchlata vybrati, je ukázati veřejně, odmítnouti a pak zahoditi, kam patří“ (IBID.: 1). Pro knihy „bez obsahu, bez ducha, bez myšlenek, bez formy“ Hálek nalezl pojmenování „hluchá literatura“, a tato literatura podle něho sebrala „všecku svou sílu, odvahu i drzost“ proto, že se o ní mlčelo - proto také podle Hálka není „kritikem celým, kdo jen záživného v literatuře se přidržuje, a tím, co škodí, opovrhuje“" (IBID.: 1). V těchto úvahách o otázce, zda i nekvalitní literární produkce má být předmětem kritiky, Hálek de facto obhajoval postup pražských kritiků uplatněný na počátku roku 1872 vůči Hanuši Věnceslavu Tůmovi. V jeho pozadí lze ovšem za snahou po zvýšení estetické úrovně české literatury rozpoznat také odhodlání určovat pravidla fungování tohoto prostoru a udržet si v něm vliv.

Studie vznikla s podporou na dlouhodobý koncepční rozvoj výzkumné instituce 68378068. Při její přípravě byly využity zdroje výzkumné infrastruktury Česká literární bibliografie (http://clb.ucl.cas.cz). Podklady k obrazové přiloze laskavě poskytlo Vlastivědné muzeum Dr. Hostaše v Klatovech.

\section{PRAMENY}

\section{Archivni}

\section{DUNOVSKÝ, Jan}

1871 Dunovský Jan Holečkovi Josefu (LA PNP, fond Josef Holeček, korespondence přijatá, datace „8. máje 1871“ opravena na „8. června“)

\section{KRONIKA}

1865-1914 Kronika školy 1865-1914 (Státní okresní archiv Klatovy, fond Vrchlického gymnasium Klatovy, Úřední knihy, inv. č. 1750)

TŮMA, Hanuš Věnceslav

1866-1867 Prvotiny (rukopis, soukromá sbírka)

\section{UMĚLECKÁ BESEDA}

1863-1869 Jednání literárního odboru Umělecké Besedy 1863-1869 (LA PNP, fond Umělecká beseda) 1867-1873 Kniha zápisů z let 1867-1873 (LA PNP, fond Umělecká beseda)

1870 Presenční listiny (LA PNP, fond Umělecká beseda) 
Martin Hrdina

Hanuš Věnceslav Tůma ve sporu s pražskou kritikou

\title{
Vydané
}

\section{ANONYM}

1872a „,Básně Hanuše Věnceslava Tůmy“, Český Lev 3, č. 1, 4. 1., s. 3

1872b „Jan z Dubé. Báseň Otakara Červinky“, Květy 7, č. 2, 11. 1., s. 15

1872c „Básně Hanuše Věnceslava Tůmy“, Květy 7, č. 4, 25. 1., s. 31

1872d „Literární kritika a kritikářský protektorát“, Šumavan 5, č. 4, 6-7, 9, 27. 1. - 2. 3., s. 38-39, 57, 68, 91

\author{
HÁLEK, Vítězslav \\ 1859 Večerní písně (Praha: Antonín Renn) \\ 1872a „Naše literární trhy II“, Národní listy 12, č. 239, 30. 8., s. 1 \\ 1872b „Naše literární trhy IV“, Národní listy 12, č. 246, 6. 9., s. 1 \\ 1874 „Klassikové z venkova I“", Národní listy 14, č. 49, 20. 2., s. 1
}

HELLER, Servác

1916 Z minulé doby našeho života národního, kulturního a politického. Upomínky a zápisky 1 (Praha: Český čtenář)

HOLEČEK, Josef

1886 „Sjezd spisovatelů ve Vodňanech dne 15. t. m.“, Národní listy 26, č. 228, 231, 234, 18.-24. 8., s. 1, 1, 1

NERUDA, Jan

1957 „Večerní písně. Složil Vítězslav J. Hálek [1859]“, in idem: Literatura I (Praha: SNKLHU), s. 48-50

SCHULZ, Ferdinand

1872 „Rozhledy literární“, Osvěta 2, č. 3, 1. 3., s. 317-320

TƯMA, Hanuš Věnceslav

1872a Básně (Klatovy: Max. Čermák)

1872b „Panu literárnímu referentovi ,Květư!', Šumavan 5, č. 5, 3. 2., s. 47-48

1872c „Panu Ferd. Schulzovi v Praze!“, Šumavan 5, č. 13, 30. 3., s. 135-136

\section{LITERATURA}

BOURDIEU, Pierre

2010 Pravidla umění. Vznik a struktura literárního pole, přel. Petr Kyloušek, Petr Dytrt (Brno: Host)

2014 Co se chce ř́ct mluvením. Ekonomie jazykové směny, přel. Martin Pokorný (Praha: Univerzita Karlova)

HAMAN, Aleš

1999 Nástin dějin české literární kritiky (Jinočany: H \& H)

HRDINA, Martin

2019 „Ozvěny minulosti. Rukopisy královédvorský a zelenohorský v kulturním projektu Jaroslava 
Vrchlického“, in Dalibor Dobiáš (ed.): Rukopisy královédvorský a zelenohorský v kultuře a umění (Praha: Academia), s. 681-725

JEŘÁBEK, Dušan

1959 Vitězslav Hálek a jeho úloha ve vývoji české literární kritiky 19. století (Praha: SPN)

KOVAŘíK, Petr

2010 Národní soud nad zrádcem Karlem Sabinou. (Nová fakta, policejní a soudní dokumenty, výpovědi svědků) (Praha: Modrý stůl)

MUKAŘOVSKÝ, Jan

1948 Kapitoly z české poetiky II. K vývoji české poesie a prózy (Praha: Svoboda)

PAVLÍČKOVÁ, Kamila

2006 Vodňanská léta Františka Heritese (Vodňany: Městské muzeum a galerie ve Vodňanech)

PEŠTA, Pavel

2008 „Jan Václav Tůma“, in Luboš Merhaut a kol.: Lexikon české literatury. Osobnosti, díla, instituce 4. S-Ž.

Sv. I S-T (Praha: Academia), s. 1036-1037

\section{POHORSKÝ, Miloš}

1961 „Rozvoj demokratické literatury“, in J. Brabec - J. Janáčková - M. Jankovič - K. Krejčí - Z. Pešat M. Pohorský: Dějiny české literatury III (Praha: Nakladatelství Československé akademie věd), s. 17-58

PRAŽÁK, Albert

1913 „Dějiny literárního odboru Umělecké besedy“, in Hanuš Jelínek (ed.): Padesát let umělecké besedy 1863-1913 (Praha: Umělecká beseda), s. 141-257

Mgr. Martin Hrdina, Ph.D., hrdina@ucl.cas.cz, Ústav pro českou literaturu AV ČR, Praha, Česká republika / Institute of Czech Literature of the CAS, Prague, Czech Republic 